\title{
Internal Marketing Elements and Internal Service Quality among Padang Food Restaurants
}

\author{
Suziana
}

\begin{abstract}
The purpose of this paper is to describe the pilot study as a preliminary study to test questionnaire items related to the topics of the paper. The research about relationship between Internal Marketing (IM) as $X$ variables and Internal. Service Quality (ISQ) as a Y variable and Organization Citizenship Behavior (OCB) as mediating variable on Padang food Restaurants. IM elements consists of (1)IM Employee ( recruitment, motivation, and development), IM Organization ( communication, management support, and coordination) and (3)IM Environment (support system, work environment, and competitor). ISQ variables consists of Reliability, Assurance, Tangibility, Empathy and Responsiveness). Unit analysis is individuals, who are defined as the Padang food Restaurants employees in West Sumatera Province, Indonesia. Type of research is quantitative method and data collected with a survey. Analyzed of data using of SPSS tools. The number of samples is used of 30 respondents. Respondents are employee of Padang food restaurants who worked as cooker, barista, waiter,cashier, and administrative staff. The number of questionnaire are 47 indicators and 5 variables which consists of: (1) IM employee (9 indicators), (2) IM organization (9 indicators), (3) IM environment (9 indicators), (4) OCB variable (5 indicators), and (5) ISQ variable (15 indicators). Scale of data using Likert scale. The results of the pilot test prove that every items in the of questionnaire are valid and variables are reliable. Valid means the value of corrected item-total correlation is bigger than 0.3 and reliable means the value of Cronbach's alpha is more than 0.6. It means the research will be continue to the actual study.The study can be useful for researcher to application internal marketing and internal service quality on restaurants specially Padang food restaurants. The readers can used this paper to guide the next research about internal marketing and internal service quality on any kind of restaurants.
\end{abstract}

Index Terms: pilot study, internal marketing, internal service quality, valid, reliable

\section{INTRODUCTION}

West Sumatera Province, Indonesia is famous as one of the tourist destinations with a very good potential economic development. Nowadays, tourism sector with all of its derivatives products and services as well as sub-sectors have been chosen as the major important industry for West Sumatra Province to support its macroeconomic performance. A vital industry that supports tourism in West Sumatera is Padang food restaurants - which simply translated as the restaurants originated from Padang, the capital city of the West Sumatra Province. Padang food

Revised Manuscript Received on 14 September, 2019.

Suziana, Lecturer of Universitas Andalas, Indonesia suzianaanas@gmail.com. restaurant is famous not only in Indonesia, but also to its neighbor countries such as Malaysia, Singapore, etc. One of the typical cuisines in Padang restaurant is rendang - the caramelized beef, which has been chosen by $\mathrm{CNN}$ as one of the most delicious food in the world.

However, the development of Padang food restaurants faces a serious problem as it is in high demand to increase the quality of the services [1]. Due to its traditional rooted and very specific culinary industry, Padang restaurant has long been enjoyed a "superiority" in the culinary business in Indonesia, with low competition rate from other type of culinary business. Every Indonesian people knows Padang restaurant well - and as the result, Padang food restaurant took many benefits from that food situation. The recent development however, shows that there are significant increasing competitions between Padang food restaurant and the new types of culinary and between Padang food restaurant themselves. This has resulted a stricter competition which require continuous and up-dated competitive strategies applied by Padang restaurants.

An important competitive strategy that can be chosen and used by Padang food restaurants is through the implementation of internal marketing, in which this paper is focused at. So, this paper will try to reveal the facts of internal marketing elements of Padang food restaurant which in the preliminary stage was undertaken as the pilot study.

The pilot study is a preliminary research study before conducting the actual study. It uses the validity test and the reliability test to the construct of the research/study. Validity test is used to measure the validity of each items in the questionnaire. This was done by finding the value of corrected item-total correlation. As a rule, if its value is more than 0.3 then it means the question is valid.

Meanwhile, the reliability test is used to measure whether the research instrument used in the research is reliable or not. A reliable question means that the question could be used to measure the same object in several times and it predictably would extract the same output. Reliability test to all items in the research instrument usually uses the value of Cronbach's alpha as the coefficient. A construct is reliable if its value is more than $0.60(>0.60)$.

\section{LITERATURE REVIEW}

Dadan and Firmansyah (2009) define the Padang food restaurant as the place that serves Padang food or Minang cuisine. It is the most popular food in Southeast Asia. Padang 
food restaurants development faces a serious problem that is many restaurants need to increase their service (Sinti, 2014).

Internal Marketing (IM) is simply understood as the marketing on employee. In principle, IM must take place on two levels. At one level, the various marketing functions must work together and at the second level, other departments must embrace marketing, in which they must also think about the customers (Kotler, P. \& Keller K.L. 2012).

Internal marketing is a planned effort using a marketing like approach directed at motivating employees, for implementing and integrating organizational strategies towards customer orientation (Ahmed and Rafiq, 2002).

The research creates contradictory ideas of whether it is important to start with internal or external marketing in order obtain success (Lings, 1999). IM is the holistic marketing principle and strategy. In IM, all variables in the organization must be involved within the marketing process. The conceptual model defined that internal marketing elements consist of three major consideration, as follows: (1) employee (2) organization, and (3) environment.

Organizational Citizenship Behavior (OCB) is conceptualized as synonymous with the concept of contextual performance, which is defined as the performance that supports the social and psychological environment, where the task performance takes place.

Internal Service Quality (ISQ) is used in this research as dependent variable. This study considers ISQ as the level on how employees within an organization satisfied with their job. According to Parasuraman (1991), the internal service quality consists of and is formed from five dimensions, which are: [1] reliability, [2] assurance, [3] tangibility, [4] empathy, and [5] responsiveness.

Scholars of Internal Service Quality such as Berry and Parasuraman (1991) indicated that organizations must attract qualified employees whose personal values match the firm's values. Hence, the main objective is to hire the right talents who are capable to understand the different products and services provided as the traditional approach for employees' recruitment that was "compete for talent" is now replaced with "compete for the right talent".

Nickson et al. (2005) found that recruitment process has major focus on employees' personality characteristics and self-presentation traits that are very important for the success of the service encounter and building a service companies image in the hospital industry. In a study conducted in the hotel industry, Yurtseven and Halici (2012) found the hotels' staff place high level importance on the cooperation among the employees and being sufficiently qualified as main factors to enhance their motivation to work, which will lead to a higher level of satisfaction.

The pilot test is test of instruments before conducting the actual study. The test of instrument used to obtain more valid and reliable empirically.Valid instrument means the instrument can be used to measure what should be measured. The minimum requirement to be eligible validity is if $r$ count more than 0.3 . Reliability testing performed using cronbach alpha formula. In general, variable is reliable which cronbach alpha more than 0.6 (Nurmally,1978)

The research concept of model that shown on the figure 1 .

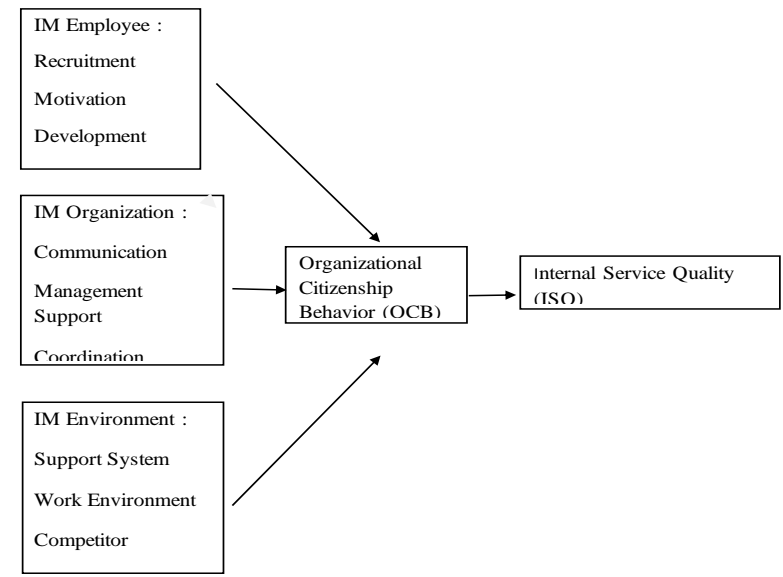

Fig 1 Conceptual Model

\section{METHODOLOGY}

This paper uses quantitative methodology to investigate and examine the validity and reliability of research instrument that will be used during the data collection. The validity of research instrument is measured by measuring the correlation of each item in the questionnaire. Meanwhile, the reliability test is measured by using Cronbach's Alpha of each variable and dimension of the study. Statistical software in the form of SPSS 23.0 is used as the main tool to analyze the data from survey.

The number of samples used in this pilot study is 30 respondents, consist of employees of Padang restaurants in West Sumatera. The questionnaire is used as the research instrument and it consists of 47 items/questions.

The variables of the research are:

1. Independent variables : IM employee, IM organization, IM environment

2. Mediating Variable : Organization Citizenship Behavior (OCB)

3. Dependent Variable : Internal Service Quality (ISQ)

To collect the data, the study will use the survey method. Each step of the research during the study is shown in the following figure 2 .

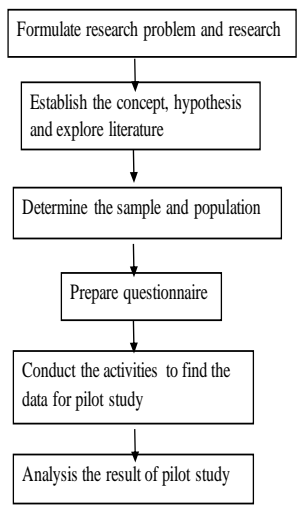

Fig 2. Steps of Research

Published By: Blue Eyes Intelligence Engineering 


\section{DISCUSSION / ANALYSIS}

Data was collect from survey and then item questionnaire has been test with Validity and Reliability.

\section{A. Validity Test}

1) Correlation Internal Marketing Elements (IM) of Employee Variable

Table 1 Correlation among item of Employee Recruitment Correlations

\begin{tabular}{llllll}
\hline & & ER1 & ER2 & ER3 & TOT_ER \\
\hline ER1 & Pearson Correlation & 1 & $.588^{\prime \prime}$ & .303 & $.796^{\prime \prime}$ \\
& Sig. (2-tailed) & & .001 & .103 & .000 \\
& $\mathrm{~N}$ & 30 & 30 & 30 & 30 \\
\hline ER2 & Pearson Correlation & $.588^{\prime \prime}$ & 1 & $.479^{\prime \prime}$ & $.892^{\prime \prime}$ \\
& Sig. (2-tailed) & .001 & & .007 & .000 \\
& $\mathrm{~N}$ & 30 & 30 & 30 & 30 \\
ER3 & Pearson Correlation & .303 & $.479^{\prime \prime}$ & 1 & $.703^{\prime \prime}$ \\
& Sig. (2-tailed) & .103 & .007 & & .000 \\
& $\mathrm{~N}$ & 30 & 30 & 30 & 30 \\
\cline { 2 - 6 } TOT_ER & Pearson Correlation & $.796^{\prime \prime}$ & $.892^{\prime \prime}$ & $.703^{\prime \prime}$ & 1 \\
& Sig. (2-tailed) & .000 & .000 & .000 & \\
& $\mathrm{~N}$ & 30 & 30 & 30 & 30 \\
\cline { 2 - 5 } & & & & &
\end{tabular}

Table 1 shows the correlation of ER1 (Employee Recruitment 1) means Variable of employee from Internal Marketing Elements with recruitment item question 1:

"This restaurant has employee to rely on" is valid. It means value of Pearson correlation is 0.796 bigger from 0.3.The value of Pearson Correlation of ER2 (item2) is 0.892 and it means valid. ER3 (item 3) is valid too because the value of Pearson Correlation is 0.703 .

Table 2. Correlation among items of Employee Motivation

\begin{tabular}{|c|c|c|c|c|c|}
\hline \multicolumn{6}{|c|}{ Correlations } \\
\hline & & EM4 & EM5 & EM6 & TOT_EM \\
\hline \multirow[t]{3}{*}{ EM4 } & Pearson Correlation & 1 & $.549^{\prime \prime}$ & .318 & $.718^{\prime \prime}$ \\
\hline & Sig. (2-tailed) & & .002 & .086 & .000 \\
\hline & N & 30 & 30 & 30 & 30 \\
\hline \multirow[t]{3}{*}{ EM5 } & Pearson Correlation & $.549^{\prime \prime}$ & 1 & $.497^{\circ}$ & $.863^{\prime \prime}$ \\
\hline & Sig. (2-tailed) & .002 & & .005 & .000 \\
\hline & N & 30 & 30 & 30 & 30 \\
\hline \multirow[t]{3}{*}{ EM6 } & Pearson Correlation & .318 & $.497^{*}$ & 1 & $.801^{\prime}$ \\
\hline & Sig. (2-tailed) & .086 & .005 & & .000 \\
\hline & $\mathrm{N}$ & 30 & 30 & 30 & 30 \\
\hline \multirow[t]{3}{*}{ TOT_EM } & Pearson Correlation & $.718^{\prime \prime}$ & $.863^{\prime \prime}$ & $.801^{\prime \prime}$ & 1 \\
\hline & Sig. (2-tailed) & .000 & .000 & .000 & \\
\hline & N & 30 & 30 & 30 & 30 \\
\hline
\end{tabular}

Table 2 shows that the correlation EM1 (Employee Motivation 4) means the variable of employee from Internal Marketing Elements with motivation item question 4:

"I knows about the motivation "is valid. It means value of Pearson correlation is 0.718 bigger from 0.3 .The value of Pearson Correlation of EM5 (item 5) is 0.863 and it means valid. EM6 (item 6) is valid too because the value of Pearson Correlation is 0801 .
Table 3. Correlation among item of Employee Development

\begin{tabular}{|c|c|c|c|c|c|}
\hline \multicolumn{6}{|c|}{ Correlations } \\
\hline & & ED7 & ED8 & ED9 & TOT_ED \\
\hline \multirow[t]{3}{*}{ ED7 } & Pearson Correlation & 1 & .227 & $.537^{\prime \prime}$ & $.735^{*}$ \\
\hline & Sig. (2-tailed) & & .228 & .002 & .000 \\
\hline & N & 30 & 30 & 30 & 30 \\
\hline \multirow[t]{3}{*}{ ED8 } & Pearson Correlation & .227 & 1 & $.419^{*}$ & $.747^{\prime \prime}$ \\
\hline & Sig. (2-tailed) & .228 & & .021 & .000 \\
\hline & N & 30 & 30 & 30 & 30 \\
\hline \multirow[t]{3}{*}{ ED9 } & Pearson Correlation & $.537^{\prime \prime}$ & $.419^{*}$ & 1 & $.831^{\prime \prime}$ \\
\hline & Sig. (2-tailed) & .002 & .021 & & .000 \\
\hline & $\mathrm{N}$ & 30 & 30 & 30 & 30 \\
\hline \multirow[t]{3}{*}{ TOT_ED } & Pearson Correlation & $.735^{\prime \prime}$ & $.747^{\prime \prime}$ & $.831^{\prime \prime}$ & 1 \\
\hline & Sig. (2-tailed) & .000 & .000 & .000 & \\
\hline & $\mathrm{N}$ & 30 & 30 & 30 & 30 \\
\hline
\end{tabular}

Table 3 above that correlation ED7 (Employee Development 7 ) means Variable of employee from Internal Marketing Elements with development item question 7:

"This restaurant gives a training opportunity" is valid. It means value of Pearson correlation is 0.735 bigger from 0.3.The value of Pearson Correlation of ED8(item 8) is 0.747 and it means valid. ED9 (item 9) is valid too because the value of Pearson Correlation is 0.831 .The all of questions of employee variable ( item 1 until 9 ) on 9 items are valid.

2) Internal Marketing Element of Organization Variable

Table 4. Correlation among Items of Organization Communication

\begin{tabular}{|c|c|c|c|c|c|}
\hline \multicolumn{6}{|l|}{ Correlations } \\
\hline & & OCOM10 & OCOM11 & OCOM12 & TOT_OCOM \\
\hline \multirow[t]{3}{*}{ OCOM10 } & Pearson Correlation & 1 & $.616^{\prime \prime}$ & $.661^{*}$ & $.884^{*}$ \\
\hline & Sig. (2-tailed) & & .000 & .000 & .000 \\
\hline & $\mathrm{N}$ & 30 & 30 & 30 & 30 \\
\hline \multirow[t]{3}{*}{ OCOM11 } & Pearson Correlation & $.616^{\prime \prime}$ & 1 & $.581^{*}$ & $.820^{\circ}$ \\
\hline & Sig. (2-tailed) & .000 & & .001 & .000 \\
\hline & $\mathrm{N}$ & 30 & 30 & 30 & 30 \\
\hline \multirow[t]{3}{*}{ OCOM12 } & Pearson Correlation & $.661^{\prime \prime}$ & $.581^{\prime \prime}$ & 1 & $.885^{\prime \prime}$ \\
\hline & Sig. (2-tailed) & .000 & .001 & & .000 \\
\hline & $\mathrm{N}$ & 30 & 30 & 30 & 30 \\
\hline \multirow[t]{3}{*}{ TOT_OCOM } & Pearson Correlation & $.884^{\prime \prime}$ & $.820^{\circ}$ & $.885^{\prime \prime}$ & 1 \\
\hline & Sig. (2-tailed) & .000 & .000 & .000 & \\
\hline & $\mathrm{N}$ & 30 & 30 & 30 & 30 \\
\hline
\end{tabular}

Table 4 explain that correlation OCOM110 (Organization Communication 10 ) means Variable of Organization from Internal Marketing Elements with communication item question 10 : "The vertical communication was doing smoothly" is valid. It means value of Pearson correlation is 0.884 bigger from 0.3.The value of Pearson Correlation of OCOM11 (item 11) is 0.820 and it means valid. OCOM12 (item 12) is valid too because the value of Pearson Correlation is 0.885 . 
Table 5. Correlation among Items of Organization Management

\begin{tabular}{|c|c|c|c|c|c|}
\hline \multicolumn{6}{|c|}{ Correlations } \\
\hline & & OM13 & OM14 & OM15 & TOT_OM \\
\hline \multirow[t]{3}{*}{ OM13 } & Pearson Correlation & 1 & $.601 "$ & $.421^{\circ}$ & $.841^{\prime \prime}$ \\
\hline & Sig. (2-tailed) & & .000 & .020 & .000 \\
\hline & $\mathrm{N}$ & 30 & 30 & 30 & 30 \\
\hline \multirow[t]{3}{*}{ OM14 } & Pearson Correlation & $.601^{*}$ & 1 & $.467^{*}$ & $.848^{\prime \prime}$ \\
\hline & Sig. (2-tailed) & .000 & & .009 & .000 \\
\hline & $\mathrm{N}$ & 30 & 30 & 30 & 30 \\
\hline \multirow[t]{3}{*}{ OM15 } & Pearson Correlation & $.421^{\circ}$ & $.467^{\prime \prime}$ & 1 & $.755^{*}$ \\
\hline & Sig. (2-tailed) & .020 & .009 & & .000 \\
\hline & $\mathrm{N}$ & 30 & 30 & 30 & 30 \\
\hline \multirow[t]{3}{*}{ TOT_OM } & Pearson Correlation & $.841^{\prime \prime}$ & $.848^{\prime \prime}$ & $.755^{\prime \prime}$ & 1 \\
\hline & Sig. (2-tailed) & .000 & .000 & .000 & \\
\hline & $\mathrm{N}$ & 30 & 30 & 30 & 30 \\
\hline
\end{tabular}

Table 5 present that correlation OM113 (Organization Management Support 13 ) means Variable of Organization from Internal Marketing Elements with Management Support item question 13

"The management always supports employee in the work" is valid. It means value of Pearson correlation is 0.841 bigger from 0.3.The value of Pearson Correlation of OM13 (item 14) is 0.848 and it means valid. OM15 (item 15) is valid too because the value of Pearson Correlation is 0755 .

Table 6. Correlation among Items of Organization

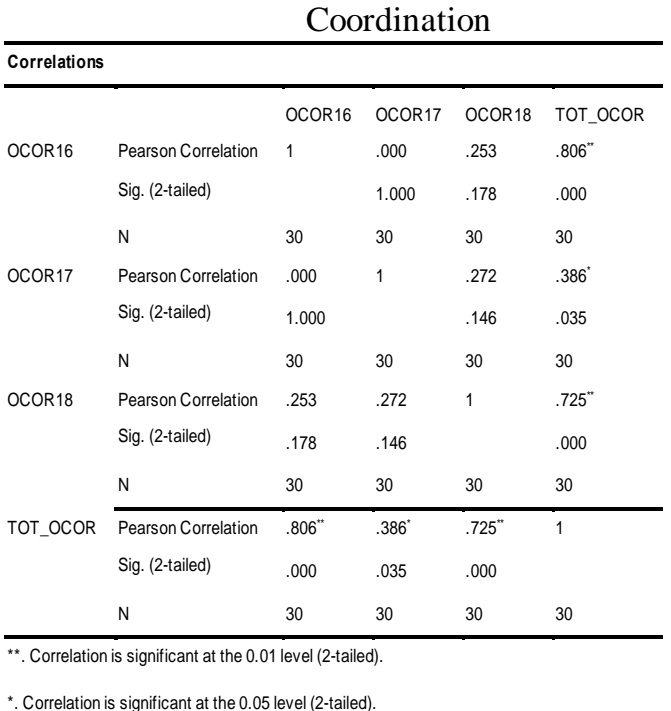

Table 6 shows that correlation OCOR16 (Organization Coordination 16 ) means Variable of Organization from Internal Marketing Elements with Coordination item question 16 :"This restaurant have a shift work's system" is valid. It means value of Pearson correlation is 0.806 bigger from 0.3.The value of Pearson Correlation of OCOR17 (item 17 ) is 0.386 and it means valid. OCOR18 (item 18) is valid too because the value of Pearson Correlation is 0.725 . The all of questions of organization variable (item 10 until 18) on 9 items are valid.

\section{3) Internal Marketing Element of Environment Variable}

Table 7. Correlation among Items of Environment Support

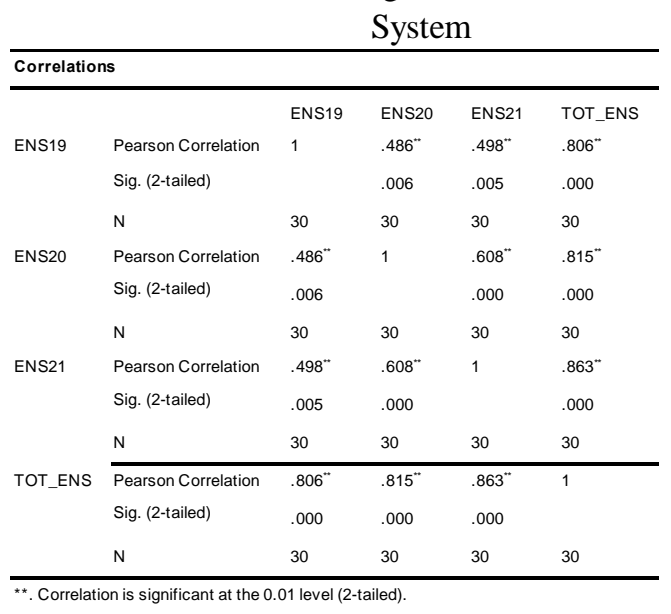

Table 7 explained that correlation ENS19 ( Environment Support System 19 ) means Variable of Environment from Internal Marketing Elements with Support System item question 19 : "This restaurant set aside food with online" is valid. It means value of Pearson correlation is 0.806 bigger from 0.3.The value of Pearson Correlation of ENS20 (item 20 ) is 0.815 and it means valid. ENS21 (item 21) is valid too because the value of Pearson Correlation is 0.863 .

Table 8. Correlation among Items of Environment Work

\begin{tabular}{|c|c|c|c|c|c|}
\hline & & En & ronm & $n t$ & \\
\hline Correlation & & & & & \\
\hline & & ENW22 & ENW23 & ENW24 & TOT_ENW \\
\hline ENW22 & Pearson Correlation & 1 & $.701^{*}$ & .190 & $.775^{\prime \prime}$ \\
\hline & Sig. (2-tailed) & & .000 & .315 & .000 \\
\hline & $\mathrm{N}$ & 30 & 30 & 30 & 30 \\
\hline ENW23 & Pearson Correlation & $.701^{*}$ & 1 & $.554^{\prime \prime}$ & $.933^{*}$ \\
\hline & Sig. (2-tailed) & .000 & & .002 & .000 \\
\hline & N & 30 & 30 & 30 & 30 \\
\hline ENW24 & Pearson Correlation & .190 & $.554^{\prime \prime}$ & 1 & $.718^{\prime \prime}$ \\
\hline & Sig. (2-tailed) & .315 & .002 & & .000 \\
\hline & N & 30 & 30 & 30 & 30 \\
\hline TOT_ENW & Pearson Correlation & $.775^{\prime \prime}$ & $.933^{\prime \prime}$ & $.718^{\prime \prime}$ & 1 \\
\hline & Sig. (2-tailed) & .000 & .000 & .000 & \\
\hline & $\mathrm{N}$ & 30 & 30 & 30 & 30 \\
\hline
\end{tabular}

Table 8 presents the correlation of ENW22 (Environment Work Environment 22), which means that the Variable of Environment from Internal Marketing Elements with Work Environment item question 22: "I work on safety place" is valid. It means value of Pearson correlation is 0.775 bigger from 0.3.The value of Pearson Correlation of ENW23 (item 23 ) is 0.993 and it means valid. ENW24 (item 24) is valid too because the value of Pearson Correlation is 0.718 . 
Table 9. Correlation among Items of Environment Competitor

\begin{tabular}{|c|c|c|c|c|c|}
\hline \multicolumn{6}{|c|}{ Correlations } \\
\hline & & ENC25 & ENC25 & ENC27 & TOT_ENC \\
\hline \multirow[t]{3}{*}{ ENC25 } & Pesrson Correlstion & 1 & $.584^{-}$ & $565^{\circ}$ & $913^{-}$ \\
\hline & sb-(2-talled) & & .001 & .001 & .000 \\
\hline & $\mathrm{N}$ & 30 & 30 & 30 & 30 \\
\hline \multirow[t]{3}{*}{$\mathrm{BNC26}$} & reserson Correlation & $.584^{*}$ & 1 & $516^{-}$ & $.790^{-}$ \\
\hline & So- (2-talled) & .001 & & .004 & .000 \\
\hline & $\mathrm{N}$ & 30 & 30 & 30 & 30 \\
\hline \multirow[t]{3}{*}{ ENC27 } & Pestron Correlation & $.565^{\circ}$ & $.516^{-}$ & 1 & $792^{-}$ \\
\hline & $s b-(2-t a \mid l e d)$ & .001 & .004 & & .000 \\
\hline & N & 30 & 30 & 30 & 30 \\
\hline \multirow[t]{3}{*}{ TOT_ENC } & Pesrson Correlation & $.913^{-}$ & $.790^{-}$ & $.792^{-}$ & 1 \\
\hline & Sb-(2-talled) & .000 & .000 & $\infty 00$ & \\
\hline & $\mathrm{N}$ & 30 & 30 & 30 & 30 \\
\hline
\end{tabular}

Table 9 shows that correlation ENC25 ( Environment Competitor 25 ) means Variable of Environment from Internal Marketing Elements with Competitor item question 25 : "This restaurant has the competitors " is valid. It means value of Pearson correlation is 0.913 bigger from 0.3.The value of Pearson Correlation of ENC26 (item 26) is 0.790 and it means valid. ENC27 (item 27) is valid too because the value of Pearson Correlation is 0.792 . The all of questions of environment variable (item 19 until 27) on 9 items are valid.

\section{4) Organizational Citizenship Behavior (OCB) Variable}

Table 10. Correlation among Items of OCB

\begin{tabular}{|c|c|c|c|c|c|c|c|}
\hline \multicolumn{8}{|c|}{ Correlations } \\
\hline & & OCB1 & осв2 & OCB3 & OCB4 & OCB5 & TOT_OCB \\
\hline \multirow[t]{3}{*}{ OCB1 } & Pearson Correlation & 1 & .059 & .233 & .355 & .167 & $.598^{\prime \prime}$ \\
\hline & Sig. (2-tailed) & & .759 & .215 & .054 & .378 & .000 \\
\hline & $\mathrm{N}$ & 30 & 30 & 30 & 30 & 30 & 30 \\
\hline \multirow[t]{3}{*}{ ОСВ2 } & Pearson Correlation & .059 & 1 & $.434^{\circ}$ & $.371^{\circ}$ & $.582^{*}$ & $.688^{\prime \prime}$ \\
\hline & Sig. (2-tailed) & .759 & & .017 & .043 & .001 & .000 \\
\hline & $\mathrm{N}$ & 30 & 30 & 30 & 30 & 30 & 30 \\
\hline \multirow[t]{3}{*}{ ОСВ3 } & Pearson Correlation & .233 & $.434^{\circ}$ & 1 & .255 & .160 & $.681^{\prime \prime}$ \\
\hline & Sig. (2-tailed) & .215 & .017 & & .175 & .399 & .000 \\
\hline & $\mathrm{N}$ & 30 & 30 & 30 & 30 & 30 & 30 \\
\hline \multirow[t]{3}{*}{ OCB4 } & Pearson Correlation & .355 & $.371^{\circ}$ & .255 & 1 & $.504^{*}$ & $.706^{*}$ \\
\hline & Sig. (2-tailed) & .054 & .043 & .175 & & .004 & .000 \\
\hline & $\mathrm{N}$ & 30 & 30 & 30 & 30 & 30 & 30 \\
\hline \multirow[t]{3}{*}{ OCB5 } & Pearson Correlation & .167 & $.582^{\prime \prime}$ & .160 & $.504^{\prime \prime}$ & 1 & $.656^{\prime \prime}$ \\
\hline & Sig. (2-tailed) & .378 & .001 & .399 & .004 & & .000 \\
\hline & $\mathrm{N}$ & 30 & 30 & 30 & 30 & 30 & 30 \\
\hline \multirow[t]{3}{*}{ TOT_OCB } & Pearson Correlation & $.598^{\prime \prime}$ & $.688^{\prime \prime}$ & $.681^{\prime \prime}$ & $.706^{\prime \prime}$ & $.656^{\prime \prime}$ & 1 \\
\hline & Sig. (2-tailed) & .000 & .000 & .000 & .000 & .000 & \\
\hline & $\mathrm{N}$ & 30 & 30 & 30 & 30 & 30 & 30 \\
\hline
\end{tabular}

*. Correlation is significant at the 0.05 level (2-tailed).

Table 10 present that correlation OCB1 (Organizational Citizenship Behavior 1) means Variable of Organizational Citizenship Behavior item question 1 : "I help colleague mutually on the work " is valid. It means value of Pearson correlation is 0.598 bigger from 0.3.The value of Pearson Correlation of OCB2 (item 2) is 0.688 and it means valid. OCB3 (item 3) is valid too because the value of Pearson Correlation is 0.681. Furthermore, OCB4 (item 4 ) the value of Pearson Correlation is 0.706 and OCB5 (item 5) is 0.656 are valid. The all of questions of OCB variable on 5 items are valid.
5) Internal Service Quality (ISQ) Variable Table 11. Correlation among Items of ISQ Reliability

\begin{tabular}{|c|c|c|c|c|c|}
\hline \multicolumn{6}{|c|}{ Correlations } \\
\hline & & IREL1 & IREL2 & IREL3 & TOT_IREL \\
\hline \multirow[t]{3}{*}{ IREL1 } & Pearson Correlation & 1 & $.549^{\prime \prime}$ & $.789^{\prime \prime}$ & $.912^{*}$ \\
\hline & Sig. (2-tailed) & & .002 & .000 & .000 \\
\hline & $\mathrm{N}$ & 30 & 30 & 30 & 30 \\
\hline \multirow[t]{3}{*}{ IREL2 } & Pearson Correlation & $.549^{\prime \prime}$ & 1 & .331 & $.791^{\prime \prime}$ \\
\hline & Sig. (2-tailed) & .002 & & .074 & .000 \\
\hline & $\mathrm{N}$ & 30 & 30 & 30 & 30 \\
\hline \multirow[t]{3}{*}{ IREL3 } & Pearson Correlation & $.789^{\prime \prime}$ & .331 & 1 & $.808^{\prime \prime}$ \\
\hline & Sig. (2-tailed) & .000 & .074 & & .000 \\
\hline & $\mathrm{N}$ & 30 & 30 & 30 & 30 \\
\hline \multirow[t]{3}{*}{ TOT_IREL } & Pearson Correlation & $.912^{\prime \prime}$ & $.791^{\prime \prime}$ & $.808^{\prime \prime}$ & 1 \\
\hline & Sig. (2-tailed) & .000 & .000 & .000 & \\
\hline & $\mathrm{N}$ & 30 & 30 & 30 & 30 \\
\hline
\end{tabular}

Table 11 present that correlation IREL1 (Internal Service Quality Reliability 1) means Variable of Internal Service Quality on Reliability item question 1

" The management serves employee kindly " is valid. It means value of Pearson correlation is 0.912 bigger from 0.3.The value of Pearson Correlation of IREL2 (item 2) is 0.791 and it means valid.IREL3 (item 3 ) is valid too because the value of Pearson Correlation is 0.808 .

Table 12. Correlation among Items of ISQ Assurance

\begin{tabular}{|c|c|c|c|c|c|}
\hline \multicolumn{6}{|c|}{ Correlations } \\
\hline & & IA4 & IA5 & IA6 & TOT_IA \\
\hline \multirow[t]{3}{*}{ IA4 } & Pearson Correlation & 1 & $.453^{\circ}$ & $.633^{\prime \prime}$ & $.889 "$ \\
\hline & Sig. (2-tailed) & & .012 & .000 & .000 \\
\hline & $\mathrm{N}$ & 30 & 30 & 30 & 30 \\
\hline \multirow[t]{3}{*}{ IA5 } & Pearson Correlation & $.453^{\circ}$ & 1 & $.414^{\circ}$ & $.724 "$ \\
\hline & Sig. (2-tailed) & .012 & & .023 & .000 \\
\hline & $\mathrm{N}$ & 30 & 30 & 30 & 30 \\
\hline \multirow[t]{3}{*}{ IA6 } & Pearson Correlation & $.633^{\prime \prime}$ & $.414^{\circ}$ & 1 & $.830^{\circ}$ \\
\hline & Sig. (2-tailed) & .000 & .023 & & .000 \\
\hline & $\mathrm{N}$ & 30 & 30 & 30 & 30 \\
\hline \multirow[t]{3}{*}{ TOT_IA } & Pearson Correlation & $.889^{\prime \prime}$ & $.724 "$ & $.830^{\prime \prime}$ & 1 \\
\hline & Sig. (2-tailed) & .000 & .000 & .000 & \\
\hline & $\mathrm{N}$ & 30 & 30 & 30 & 30 \\
\hline
\end{tabular}

Table 12 shows that correlation A4 (Internal Service Quality Assurance 4) means Variable of Internal Service Quality on Assurance item question 4 :

" The employee serves customer politely " is valid. It means value of Pearson correlation is 0.889 bigger from 0.3.The value of Pearson Correlation of IA5 (item 5) is 0.724 and it means valid.IA6 (item 6) is valid too because the value of Pearson Correlation is 0.830 . 
Table 13. Correlation among Items of ISQ Tangibility

\begin{tabular}{|c|c|c|c|c|c|}
\hline \multicolumn{6}{|c|}{ Correlations } \\
\hline & & IT7 & IT8 & IT9 & TOT_IT \\
\hline \multirow[t]{3}{*}{ IT7 } & Pearson Correlation & 1 & $.806^{\prime \prime}$ & .351 & $.904^{*}$ \\
\hline & Sig. (2-tailed) & & .000 & .057 & .000 \\
\hline & $\mathrm{N}$ & 30 & 30 & 30 & 30 \\
\hline \multirow[t]{3}{*}{ IT8 } & Pearson Correlation & $.806^{*}$ & 1 & .267 & $.871^{*}$ \\
\hline & Sig. (2-tailed) & .000 & & .154 & .000 \\
\hline & $\mathrm{N}$ & 30 & 30 & 30 & 30 \\
\hline \multirow[t]{3}{*}{ IT9 } & Pearson Correlation & .351 & .267 & 1 & $.641^{\prime \prime}$ \\
\hline & Sig. (2-tailed) & .057 & .154 & & .000 \\
\hline & N & 30 & 30 & 30 & 30 \\
\hline \multirow[t]{3}{*}{ TOT_IT } & Pearson Correlation & $.904^{\prime \prime}$ & $.871^{\prime \prime}$ & $.641^{\prime \prime}$ & 1 \\
\hline & Sig. (2-tailed) & .000 & .000 & .000 & \\
\hline & $\mathrm{N}$ & 30 & 30 & 30 & 30 \\
\hline
\end{tabular}

Table 13 present that correlation IT7 ( Internal Service Quality Tangibility 7 ) means Variable of Internal Service Quality on Tangibility item question 7

"This restaurant is clean " is valid. It means value of Pearson correlation is 0.904 bigger from 0.3.The value of Pearson Correlation of IT8 (item 8) is 0.871 and it means valid. IT9 (item 9) is valid too because the value of Pearson Correlation is 0.641 .

Table 14. Correlation among Items of ISQ Empathy

\begin{tabular}{|c|c|c|c|c|c|}
\hline \multicolumn{6}{|c|}{ Correlations } \\
\hline & & IE10 & IE11 & IE12 & TOT_IE \\
\hline \multirow[t]{3}{*}{ IE10 } & Pearson Correlation & 1 & $.791^{*}$ & .353 & $.809^{* \prime}$ \\
\hline & Sig. (2-tailed) & & .000 & .056 & .000 \\
\hline & N & 30 & 30 & 30 & 30 \\
\hline \multirow[t]{3}{*}{ IE11 } & Pearson Correlation & $.791^{*}$ & 1 & $.501^{*}$ & $.881^{\prime \prime}$ \\
\hline & Sig. (2-tailed) & .000 & & .005 & .000 \\
\hline & N & 30 & 30 & 30 & 30 \\
\hline \multirow[t]{3}{*}{ IE12 } & Pearson Correlation & .353 & $.501^{*}$ & 1 & $.804^{*}$ \\
\hline & Sig. (2-tailed) & .056 & .005 & & .000 \\
\hline & N & 30 & 30 & 30 & 30 \\
\hline \multirow[t]{3}{*}{ TOT_IE } & Pearson Correlation & $.809^{\prime \prime}$ & $.881^{*}$ & $.804^{*}$ & 1 \\
\hline & Sig. (2-tailed) & .000 & .000 & .000 & \\
\hline & $\mathrm{N}$ & 30 & 30 & 30 & 30 \\
\hline
\end{tabular}

**. Correlation is significant at the 0.01 level (2-tailed).

Table 14 shows that correlation IE10 ( Internal Service Quality Empathy 10 ) means Variable of Internal Service Quality on Empathy item question 10 : "The employee have a schedule to eat and rest " is valid. It means value of Pearson correlation is 0.809 bigger from 0.3.The value of Pearson Correlation of IIE11 (item 11) is 0.881 and it means valid. IE12 item 12 is valid, because the value of Pearson Correlation is 0.804 .
Table 15 Correlation among Items of ISQ Responsiveness

\begin{tabular}{|c|c|c|c|c|c|}
\hline \multicolumn{6}{|c|}{ Correlations } \\
\hline & & IRES13 & IRES14 & IRES15 & TOT_IRES \\
\hline \multirow[t]{3}{*}{ IRES13 } & Pearson Correlation & 1 & .252 & $.381^{\circ}$ & $.721^{\prime \prime}$ \\
\hline & Sig. (2-tailed) & & .178 & .038 & .000 \\
\hline & $\mathrm{N}$ & 30 & 30 & 30 & 30 \\
\hline \multirow[t]{3}{*}{ IRES14 } & Pearson Correlation & .252 & 1 & $.821^{\prime \prime}$ & $.822^{\prime \prime}$ \\
\hline & Sig. (2-tailed) & .178 & & .000 & .000 \\
\hline & $\mathrm{N}$ & 30 & 30 & 30 & 30 \\
\hline \multirow[t]{3}{*}{ IRES15 } & Pearson Correlation & $.381^{\circ}$ & $.821^{\prime \prime}$ & 1 & $.882 "$ \\
\hline & Sig. (2-tailed) & .038 & .000 & & .000 \\
\hline & $\mathrm{N}$ & 30 & 30 & 30 & 30 \\
\hline \multirow[t]{3}{*}{ TOT_IRES } & Pearson Correlation & $.721^{\prime \prime}$ & $.822^{\prime \prime}$ & $.882^{\prime \prime}$ & 1 \\
\hline & Sig. (2-tailed) & .000 & .000 & .000 & \\
\hline & $\mathrm{N}$ & 30 & 30 & 30 & 30 \\
\hline
\end{tabular}

Table 15 present that correlation IRES13 ( Internal Service Quality Responsiveness 13 ) means Variable of Internal Service Quality on Responsiveness item question 13: "The employee solved the problems together " is valid. It means value of Pearson correlation is 0.721 bigger from 0.3.The value of Pearson Correlation of IRES14 (item 14) is 0.822 and it means valid.IRES14 (item 15) is valid too because the value of Pearson Correlation is 0.882 . The all of questions of ISQ variable on 15 items are valid. It means the research continued to actual study.

\section{B. Reliability Test}

Table 16. Reliability Results

\begin{tabular}{llll}
\hline No. & Variable & No. of Item & Cronbach's Alpha \\
\hline 1 & Employee (Internal Marketing Element 1) & 9 & 0.698 \\
2 & Organization ( Internal Marketing Element 2) & 9 & 0.835 \\
3 & Environment ( Internal Marketing Element 3) & 9 & 0.835 \\
4 & Organizational Citizenship Behavior & 5 & 0.860 \\
5 & Internal Service Quality & 15 & 0.661 \\
\hline
\end{tabular}

Reliability test measures the level of reliability of all questions in the questionnaire. As a rule, questions in the questionnaire are considered reliable if the value of Cronbach's Alpha is $\geq 0.60$. It is found in the pilot study shows that table 16 the value of Cronbach's Alpha for questions in the variable employee is 0.698 . The value of Cronbach's alpha for question in the variable organization is 0.835 , variable of environment is 0.835 too. Furthermore, the variable of organizational Citizenship Behavior is 0.860 and the last variable internal service quality is 0.661 .This means that all questions in the all variable of research are reliable and the question could be used to measure the same object in several times. 


\section{CONCLUSION}

All items in questionnaire are valid and reliable. It means that the question could be used to measure the same object in several times and it predictably would extract the same output. All question shows the table 17.

Table 17. Questionnaire

\begin{tabular}{|c|c|}
\hline No. & IM Employee \\
\hline 1 & This restaurant has reliable employees \\
\hline 2 & This restaurant recruits quality employees \\
\hline 3 & My position at this restaurant is in accordance with my expertise \\
\hline 4 & I know about the meaning of motivation \\
\hline 5 & I understand the importance of motivation \\
\hline 6 & $\begin{array}{l}\text { I learned how my performance was assessed by restaurant } \\
\text { management }\end{array}$ \\
\hline 7 & $\begin{array}{l}\text { This restaurant provides opportunities for job training (example: how } \\
\text { to cook, dish, organize tables, serve customers, computers, etc.) }\end{array}$ \\
\hline 8 & $\begin{array}{l}\text { This restaurant has a rolling system (job changes at the same level) in } \\
\text { work }\end{array}$ \\
\hline \multirow[t]{2}{*}{9} & $\begin{array}{l}\text { This restaurant provides facilities to support employees in work (such } \\
\text { as rest rooms, prayer rooms, etc.) }\end{array}$ \\
\hline & IM Organization \\
\hline 10 & $\begin{array}{l}\text { Communication between superiors and subordinates in this restaurant } \\
\text { runs smoothly }\end{array}$ \\
\hline 11 & I can voice opinions on restaurant management \\
\hline 12 & I understand the business objectives of this restaurant \\
\hline 13 & Restaurant management always supports employees at work \\
\hline 14 & Management has a computer information system \\
\hline 15 & I can interact with colleagues or management through social media \\
\hline 16 & This restaurant has a shift work division system \\
\hline 17 & This restaurant has a clear organizational structure \\
\hline \multirow[t]{2}{*}{18} & I assess all work-related problems can be dealt with immediately \\
\hline & IM Environment \\
\hline 19 & This restaurant provides internet facilities for ordering food online \\
\hline 20 & $\begin{array}{l}\text { Management has a database / record of important restaurant } \\
\text { information }\end{array}$ \\
\hline 21 & $\begin{array}{l}\text { Information technology facilities in this restaurant strongly support my } \\
\text { work }\end{array}$ \\
\hline 22 & I work in a safe environment \\
\hline 23 & I feel happy working in this restaurant environment \\
\hline 24 & I feel this restaurant is in a healthy environment \\
\hline 25 & This restaurant has competitors (there are other Padang restaurants) \\
\hline 26 & Working in this restaurant is more fun than other restaurants \\
\hline 27 & This restaurant does various innovations (updates) \\
\hline No. & OCB \\
\hline 1 & In working employees help each other \\
\hline 2 & $\begin{array}{l}\text { Restaurant management always gives consultation and direction to } \\
\text { employees }\end{array}$ \\
\hline 3 & I have never complained / complained to the restaurant management \\
\hline 4 & I always participate in restaurant activities \\
\hline 5 & I obey restaurant regulations \\
\hline No. & ISQ \\
\hline 1 & Management serves employees well \\
\hline 2 & Employees prioritize service to customers \\
\hline 3 & Food served in accordance with consumer expectations \\
\hline 4 & Employees work serving servants politely \\
\hline 5 & Employees have expertise in their fields \\
\hline 6 & Employees work honestly \\
\hline 7 & The look of this restaurant is clean \\
\hline 8 & The environment of this restaurant is comfortable and healthy \\
\hline 9 & Parking in this restaurant is adequate \\
\hline 10 & Employees have a meal and rest schedule \\
\hline 11 & Employees think positively about customers \\
\hline 12 & Employees have mutual care \\
\hline 13 & Employees can solve problems together \\
\hline 14 & Employees respond to buyer requests quickly \\
\hline 15 & Management responds to information efficiently \\
\hline
\end{tabular}

\section{LIMITATION AND STUDY FORWARD}

This study has a limitation about object of research is Padang food restaurants, because Padang food restaurant is very unique case of restaurant. The next to the study forward can apply the variables of internal marketing and internal service quality.

\section{ACKNOWLEDGEMENT}

Researcher would like to thank Assoc.Prof. Nor Azilah binti Husin and Dr. Astri Yulia as research supervisors, for their patient guidance, enthusiastic encouragement and useful critiques of this research work.

\section{REFERENCES}

[1] Ahmed,P. K. \& Rafiq, M. (2002), Internal Marketing: Tools and Concepts for Customer- Focused Management, Butterworth Great Heinemann Britain.

[2] Berry, L.L \& Parasuraman, A. (1991), Marketing for Service, Competing Through Quality, Free Press, New York.

[3] Dadan, D \& Firmansyah, M. (2009), Bisnis Anti Bangkrut, Visi Media, Jakarta, 5-6.

[4] Kotler, P. \& Keller K.L. (2012), Marketing Management, England, Prentice Hall.

[5] Lings. I (1999), Balancing Internal and Eternal Market Orientation, Journal of Marketing Management, 15, 239-263.

[6] Nickson, D, Warhurst, C. \& Dutton, E. (2005), The importance of attitude and appearance in the service encounter in retail and hospitality, Managing Services Quality, 15 (2), 195-208.

[7] Nurmally, J.C (1978), Psychometric Theory ( $2^{\text {nd }}$ ed.), New York, NY: McGraw-Hill

[8] Parasuraman. A, Berry. \& Zeithaml. V (1991), Understanding Customer expectations of Service, Sloan Management Review, Spring.

[9] Sinti, N.A \& Setiawan, B. (2014), Food Service Performance Analysis and The Level of Customer satisfaction in the Ethnic Padang Restaurant in Bogor City, Jurnal Gizi dan Pangan, 9 (1).

[10] Yurtseven,G \& Halici. A (2012), Importance of the motivational factors affecting employees satisfaction, International Bussiness Research, 5 (1), 72-79.

\section{AUTHORS PROFILE}

Suziana, Lecturer of Universitas Andalas, Indonesia suzianaanas@ gmail.com. 